2nd International Conference on Ultrafine Grained \&

Nanostructured Materials (UFGNSM)

International Journal of Modern Physics: Conference Series

Vol. 5 (2012) 284-290

(C) World Scientific Publishing Company

DOI: $10.1142 / \mathrm{S} 2010194512002140$

\title{
EFFECTS OF PROCESS CONTROL AGENT ADDITION IN PROCESSING OF NANO-CRYSTALLINE TiB 2 VIA SHS METHOD
}

\author{
AMIN NOZARI \\ School of Metallurgy and Materials Engineering, University of Tehran, \\ Tehran, Iran \\ aminnozari@ut.ac.ir \\ ABOLGHASEM ATAIE ${ }^{1}$ \\ School of Metallurgy and Materials Engineering, University of Tehran, \\ Tehran, P.O. Box: 14395-553, Iran \\ aataie@ut.ac.ir \\ SAEED HESHMATI-MANESH \\ School of Metallurgy and Materials Engineering, University of Tehran, \\ Tehran, P.O. Box: 14395-553, Iran \\ sheshmat@ut.ac.ir
}

\begin{abstract}
Nano-crystalline titanium diboride $\left(\mathrm{TiB}_{2}\right)$ was prepared by self-propagating high-temperature synthesis through putting a hot filament on top of the compact mixture of $\mathrm{TiO}_{2}, \mathrm{H}_{3} \mathrm{BO}_{3}$ and $\mathrm{Mg}$ with a stoichiometric ratio. Effects of the addition of various chloride salts e.g. $\mathrm{NaClO}_{4}$ and $\mathrm{NH}_{4} \mathrm{Cl}$ as process control agents on phase evolution and chemical analysis and the morphology of the products were investigated by XRD and SEM techniques, respectively. Analysis of the X-ray diffraction patterns confirmed the formation of $\mathrm{TiB}_{2}$ together with some intermediate phases such as $\mathrm{Mg}_{3} \mathrm{~B}_{2} \mathrm{O}_{6}$ and $\mathrm{Mg}_{2} \mathrm{TiO}_{4}$ in as synthesized powder. $\mathrm{MgO}$ phase was detected as a major phase in the XRD patterns. Nano-crystalline $\mathrm{TiB}_{2}$ became the major phase in some of the leached samples by $\mathrm{HCl}$. The results also showed that the powder particle characteristics were influenced by the addition of the chloride salts.
\end{abstract}

Keywords: Titanium diboride $\left(\mathrm{TiB}_{2}\right)$, SHS, $\mathrm{Mg}_{3} \mathrm{~B}_{2} \mathrm{O}_{6}$, nano-crystalline, PCA.

\section{Introduction}

Titanium diboride $\left(\mathrm{TiB}_{2}\right)$ is a refractory ceramic which has excellent properties such as high melting point, high hardness, and good thermal and electrical conductivity, high wear resistance and considerable chemical stability. It is widely used as cutting tool

\footnotetext{
${ }^{1}$ Corresponding author: Tel.: +98-21-61114084; Fax: +98-21-88006076

Tehran, P.O. Box: 14395-553
} 
composites, wear resistance parts, metal melting crucibles, electrode materials and cathodes for electro-chemical processing of aluminum (Hall-Heroults process). ${ }^{1-4}$

$\mathrm{TiB}_{2}$ can be synthesized by different methods such as carbothermic/borothermic reduction of mixed oxides of titanium oxide with boron carbide, solid state reduction of $\mathrm{TiCl}_{4}, \mathrm{Mg}$ and $\mathrm{MgB}_{2}$, ball milling and self-propagating high-temperature synthesis (SHS) followed by acid leaching technique. ${ }^{4-8}$ The SHS method is a form of controlled combustion synthesis which is a simple method for preparation of advanced ceramics and composites. It is based on systems able to react exothermally when ignited and to sustain them to form a combustion wave. The temperature of the combustion can be very high (as $5000 \mathrm{~K}$ ) and the rate of wave propagation can be very rapid (as $25 \mathrm{~cm} / \mathrm{s}$ ), hence this process offers the opportunity to investigate reactions in conditions of extreme thermal gradients (as $105 \mathrm{~K} / \mathrm{cm}$ ). ${ }^{9}$ It has several advantages including low processing time and temperature, very low environmental impact, simple operation and generation of fine microstructures due to high cooling rates and finally, low costs and energy consumption. ${ }^{10,11}$

For controlling microstructure and homogeneity, different type and amount of SHS diluents can be added to the powder mixture. Khanara et al. ${ }^{10}$ and Chaichana et al. ${ }^{7}$ have reported the addition of $\mathrm{NaCl}$ for synthesis of nano-crystalline $\mathrm{TiB}_{2}$ powders.

In this study, synthesis of nano-crystalline $\mathrm{TiB}_{2}$ via $\mathrm{SHS}$ route has been investigated. The effects of addition of different kinds of diluents e.g. $\mathrm{NaCl}, \mathrm{KCl}, \mathrm{NH}_{4} \mathrm{Cl}$ and $\mathrm{NaClO}_{4}-\mathrm{H}_{2} \mathrm{O}$ were also studied.

\section{Experimental Procedure}

$\mathrm{TiO}_{2}(99 \%), \mathrm{H}_{3} \mathrm{BO}_{3}(99 \%)$ and $\mathrm{Mg}(98.5 \%)$ powders were used to synthesize $\mathrm{TiB}_{2}$. Stoichiometric amounts of reactants were mixed together according to Eq. (1). A mole of $\mathrm{NaCl}, \mathrm{KCl}$ and $\mathrm{NH}_{4} \mathrm{Cl}$, and 0.02 mole of $\mathrm{NaClO}_{4}-\mathrm{H}_{2} \mathrm{O}$ (sodium percholorate) were used separately to investigate the effects of process control agent (PCA) addition on the synthesis.

$$
5 \mathrm{Mg}+2 \mathrm{H}_{3} \mathrm{BO}_{3}+\mathrm{TiO}_{2}=\mathrm{TiB}_{2}+5 \mathrm{MgO}+3 \mathrm{H}_{2} \mathrm{O}
$$

For conducting SHS reaction, a hot filament was placed on top of the compact mixture of $\mathrm{TiO}_{2}, \mathrm{H}_{3} \mathrm{BO}_{3}$ and $\mathrm{Mg}$ with a stoichiometric ratio. All products were ground and washed by distilled water and air dried. Then the $\mathrm{MgO}$ was leached using $18 \% \mathrm{HCl}$ solution under magnetic stirring for $20 \mathrm{~min}$ at $40^{\circ} \mathrm{C}$ and air dried.

The phase analysis of the samples was investigated by XRD using a philips PW-3710 diffractometer with $\mathrm{Cu}-\mathrm{K}_{\alpha}$ radiation. The average crystallite size of $\mathrm{TiB}_{2}$ powders was calculated according to the Scherrer equation (Eq. (2)): ${ }^{12,13}$

$$
D=\frac{0.9 \lambda}{\beta(2 \theta) \cos \theta}
$$


Where $\mathrm{D}$ is the average crystallite size in $\mathrm{nm}, \lambda$ is the radiation wavelength $(0.154056$ $\mathrm{nm}$ for $\left.\mathrm{Cu}-\mathrm{K}_{\alpha}\right) \cdot \beta(2 \theta)$ is the breadth (commonly the full-widths at half maximum) of the pure diffraction profile and $\theta$ is the position of the analyzed peak maximum. The morphology of the particles was analyzed by scanning electron microscope (SEM) (CamScan MV2300).

\section{Results and Discussion}

Fig. 1-a shows the XRD pattern of the sample processed via SHS route without using any PCA. Analysis of the XRD pattern indicates coexistence of $\mathrm{TiB}_{2}, \mathrm{MgO}, \mathrm{Mg}_{2} \mathrm{TiO}_{4}$, and $\mathrm{Mg}_{3} \mathrm{~B}_{2} \mathrm{O}_{6}$ phases. In contrary to the results reported by Demircan et. al. ${ }^{14}$, traces of reactant powders were not detected. The intermediate $\mathrm{Mg}_{2} \mathrm{TiO}_{4}$ and $\mathrm{Mg}_{3} \mathrm{~B}_{2} \mathrm{O}_{6}$ phases were found may be due to the incomplete reaction of $\mathrm{Mg}, \mathrm{TiO}_{2}$ and $\mathrm{Mg}, \mathrm{H}_{3} \mathrm{BO}_{3}$ respectively. ${ }^{7}$ Although, leaching was performed with $18 \% \mathrm{HCl}$ in $40{ }^{\circ} \mathrm{C}$ for $20 \mathrm{~min}$, but still there are undesirable phases indicating that $\mathrm{MgO}$ was not completely leached and so $\mathrm{TiB}_{2}$ is observed as minor phase. Khanra et al. ${ }^{11}$ reported complete elimination of $\mathrm{MgO}$ from the synthesized powder by boiling in dilute $\mathrm{HCl}$.

Fig. 1-b shows the XRD pattern of the sample processed via SHS route using 0.02 mole $\mathrm{NaClO}_{4}-\mathrm{H}_{2} \mathrm{O}$ as a PCA. Because $\mathrm{NaClO}_{4}-\mathrm{H}_{2} \mathrm{O}$ acts as a promoter and increase the velocity of reaction, it was added less than other PCAs. Addition of $\mathrm{NaClO}_{4}-\mathrm{H}_{2} \mathrm{O}$ resulted in only slight diminishing of the $\mathrm{MgO}$ phase. Fig. 1-c indicates the XRD pattern of the sample synthesized in presence of 1 mole $\mathrm{NaCl}$ addition as a PCA. The peak intensities of $\mathrm{Mg}_{2} \mathrm{TiO}_{4}$ and $\mathrm{Mg}_{3} \mathrm{~B}_{2} \mathrm{O}_{6}$ phases were decreased to some extent. It seems that $\mathrm{NaCl}$ can enhance the reaction time of SHS and complete the reaction between reactants and formation of Ti and $\mathrm{B}$ elements. Diminution of $\mathrm{Mg}_{2} \mathrm{TiO}_{4}$ and $\mathrm{Mg}_{3} \mathrm{~B}_{2} \mathrm{O}_{6}$ phases resulted in increasing the magnitude of $\mathrm{TiB}_{2}$ phase as a final product. Fig 1-d shows the XRD pattern of the sample prepared with addition of 1 mole $\mathrm{NH}_{4} \mathrm{Cl}$. The results indicate approximately elimination of $\mathrm{Mg}_{2} \mathrm{TiO}_{4}$ phase but the minimum amount of $\mathrm{TiB}_{2}$ phase was obtained. The melting and boiling point of $\mathrm{NH}_{4} \mathrm{Cl}$ is 338 and $520^{\circ} \mathrm{C}$ respectively, though only in this range it can operate as a diluent and cannot control the process. It seems that the addition of $\mathrm{NH}_{4} \mathrm{Cl}$ encourages the formation of $\mathrm{Mg}_{3} \mathrm{~B}_{2} \mathrm{O}_{6}$ phase. Finally, Fig. 1-e shows the XRD pattern of the sample with addition of 1 mole $\mathrm{KCl}$ as a PCA. Analysis of the XRD pattern indicated $\mathrm{TiB}_{2}$ as a major phase. The large difference between melting and boiling points of $\mathrm{KCl}\left(770\right.$ and $1420^{\circ} \mathrm{C}$, respectively) may be responsible for increasing the magnitude of the $\mathrm{TiB}_{2}$ phase. Addition of $\mathrm{KCl}$ can increase the time of reaction and decrease the velocity of wave propagating. 


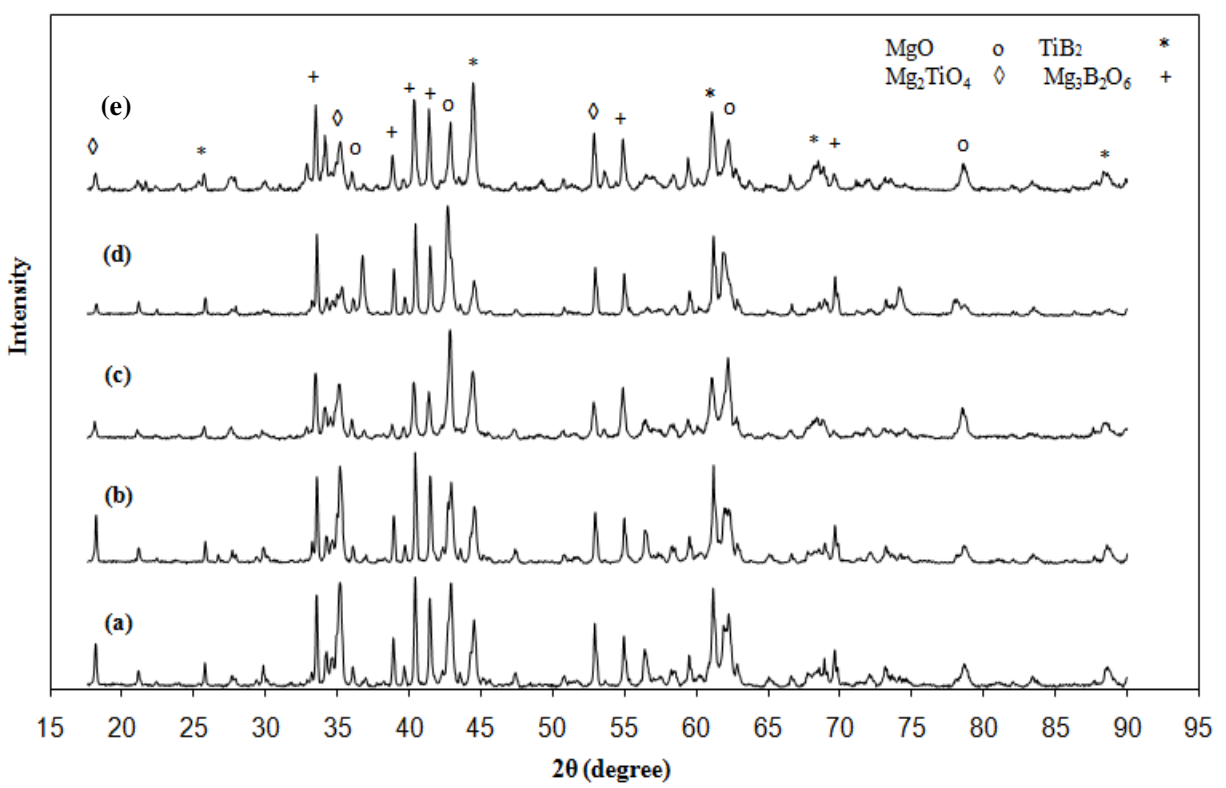

Fig 1. XRD patterns of the samples processed via SHS route (a) without PCA and with different PCAs (b) 0.02 mole $\mathrm{NaClO}_{4}-\mathrm{H}_{2} \mathrm{O}$, (c) 1 mole $\mathrm{NaCl}$, (d) 1 mole $\mathrm{NH}_{4} \mathrm{Cl}$, and (e) 1 mole $\mathrm{KCl}$.

Table 1 shows the mean crystallite size of $\mathrm{TiB}_{2}$ in the samples synthesized without and with PCA addition. As it is observed, the smallest mean crystallite size belongs to the sample produced in the presence of $\mathrm{NaCl}$. The mean crystallite size of $\mathrm{TiB}_{2}$ was reported to be $23 \mathrm{~nm}$ for the sample processed with addition of 1 mole $\mathrm{NaCl}^{1{ }^{11}}$ It seems that $\mathrm{NaCl}$ was melted during SHS process at $801{ }^{\circ} \mathrm{C}$ and further nucleation occurred in a molten zone which prevents grain and particle growth. Using $\mathrm{NaClO}_{4}-\mathrm{H}_{2} \mathrm{O}$ resulted in crystallite coarsening probably due to the exothermic nature of $\mathrm{NaClO}_{4}-\mathrm{H}_{2} \mathrm{O}$ which increases the heat of reaction.

Table 1. Mean crystallite sizes of the $\mathrm{TiB}_{2}$ particles in samples with PCAs and without PCA, calculated by Scherrer formula

\begin{tabular}{lll}
\hline PCA & Amount (mol) & $\begin{array}{l}\text { Mean crystallite } \\
\text { size }(\mathrm{nm})\end{array}$ \\
\hline- & - & 36 \\
$\mathrm{NaClO}_{4}-\mathrm{H}_{2} \mathrm{O}$ & 0.02 & 43 \\
$\mathrm{NaCl}$ & 1 & 30 \\
$\mathrm{NH}_{4} \mathrm{Cl}$ & 1 & 36 \\
$\mathrm{KCl}$ & 1 & 36 \\
\hline
\end{tabular}


SEM micrograph of the sample processed via SHS route without using any PCA exhibits large irregular shape particles with mean particle size of 2 micron together with ultra-fine spherical particles with mean particle size of almost $200 \mathrm{~nm}$ (Fig. 2-a). Uniform nano-size particles of $\mathrm{TiB}_{2}$ with mean particle size of $110 \mathrm{~nm}$ could be observed in the SEM micrograph of the sample prepared in the presence with of 0.02 mole $\mathrm{NaClO}_{4}-\mathrm{H}_{2} \mathrm{O}$ in Fig. 2-b. It seems the $\mathrm{MgO}$ acts as cement, binding the hexagonal $\mathrm{TiB}_{2}$ particles together to form a large agglomerates. ${ }^{15}$ So $\mathrm{MgO}$ and other intermediate phases could not leached completely. In the above sample, intensively exothermic nature of the reaction decreases the time of wave propagation, and as a result the particles have not opportunity to grow.
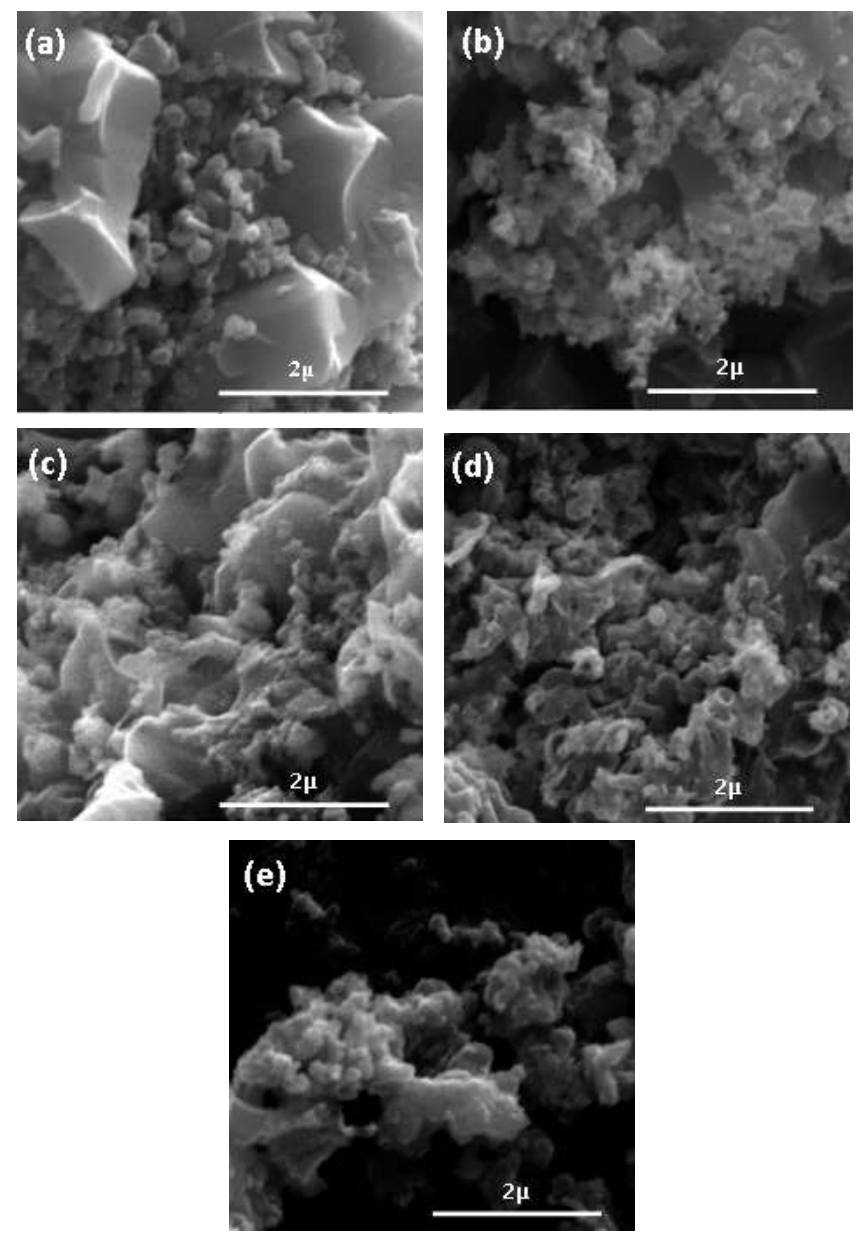

Fig 2. SEM micrographs of the samples processed via SHS route (a) without PCA and with different PCAs (b) 0.02 mole $\mathrm{NaClO}_{4}-\mathrm{H}_{2} \mathrm{O}$, (c) 1 mole $\mathrm{NaCl}$, (d) 1 mole $\mathrm{NH}_{4} \mathrm{Cl}$, and (e) 1 mole $\mathrm{KCl}$. 
Fig. 1-c indicates SEM micrograph of the sample synthesized with addition of 1 mole $\mathrm{NaCl}$. Ultra-fine particles of $\mathrm{TiB}_{2}$ were dispersed non-uniformly between some large particles; mean particle size is about $230 \mathrm{~nm}$. As mentioned by Chaichana et al. ${ }^{7}$ the melted $\mathrm{NaCl}$ that remain in the system during the SHS reaction may play an important role by coating on the nucleated $\mathrm{TiB}_{2}$ particles that could reduce their growth and finally decrease the particle sizes. Fig 1-d shows the SEM micrograph of the sample processed with addition of 1 mole $\mathrm{NH}_{4} \mathrm{Cl}$. Approximately uniform structure with agglomerated particles was observed. Amounts of $\mathrm{TiB}_{2}$ phase is less than other samples and mean particle size of products is about $180 \mathrm{~nm}$. Fig. 1-e shows the SEM micrograph of the sample with addition of 1 mole $\mathrm{KCl}$ as a diluent. Agglomerated hexagonal $\mathrm{TiB}_{2}$ phase in presence of irregular shape substrate was observed. The mean particle size is about 200 nm.

\section{Conclusions}

The SHS process was carried out with a high exothermic reaction and there was not sufficient opportunity to complete phase transformation to $\mathrm{TiB}_{2}$. The mean crystallite and particle size of the sample without any PCA was 36 and $300 \mathrm{~nm}$, respectively. It was determined that addition of PCA is an effective factor in synthesis of $\mathrm{TiB}_{2}$ in $\mathrm{SHS}$ method.

The results show that in the presence of 1 mole $\mathrm{NaCl}$, the mean crystallite size of $\mathrm{TiB}_{2}$ particles was reduced to $30 \mathrm{~nm}$, while addition of 0.02 mole $\mathrm{NaClO}_{4}-\mathrm{H}_{2} \mathrm{O}$ increases the mean crystallite size to $43 \mathrm{~nm}$. Addition of other PCAs affects the mean crystallite size. PCA addition can control the velocity of propagating wave during SHS. $\mathrm{NaClO}_{4}-\mathrm{H}_{2} \mathrm{O}$ increases the velocity and other PCAs decrease the velocity of the reaction. Reduced velocity resulted in increased SHS time and helps the formation of $\mathrm{TiB}_{2}$ phase. Although addition of $\mathrm{NaClO}_{4}-\mathrm{H}_{2} \mathrm{O}$ resulted in higher mean crystallite size, but the smaller particle size was achieved (about $110 \mathrm{~nm}$ ).

\section{Acknowledgments}

The financial support of this work by the Iran Nanotechnology Initiative Council is gratefully acknowledged.

\section{References}

1. C. Subramanian, T. S. R. Ch. Murthy, and A. K. Suri, Int. J. Refract. Metals \& Hard Mater. 25, 345 (2007).

2. A. Mukhopadhyay, G. B. Raju, B. Basu, and A. K. Suri, J. Eur. Ceram. Soc. 29, 505 (2009).

3. R. Ricceri and P. Matteazzi, Mater. Sci \& Eng. A379, 341 (2004).

4. E. Bilgi, H. E. Camurlu, B. Akgun, Y. Topkaya, and N. Sevinc, Mater. Res. Bull. 43, 873 (2008).

5. T. Saito, T. Fukuda, H. Maeda, K. Kusakabe, and S. Morooka, J. Mater. Sci. 32, 3933 (1997).

6. S. H. Kang and D. J. Kim, J. Eur. Ceram. Soc. 27, 715 (2007). 
7. N. Chaichana, N. Memongkol, J. Wannasin, and S. Niyomwas, CMU. J. Nat. Sci. Special Issue on Nanotech. 7, 51 (2008).

8. J. Y. Lok, K. V. Logan, and J. J. Payyapilly, J. Am. Ceram. Soc. 92, 26 (2009).

9. P. Mossino, Ceram. Int. 30, 311 (2004).

10. A. K. Khanra, L. C. Pathak, and M. M. Godkhindi, J. Mat. Proc. Tech. 202, 386 (2008).

11. A. K. Khanra, L. C. Pathak, S. K. Mishra, and M. M. Godkhindi, J. Mat. Let. 58, 733 (2004).

12. B. D. Cullity, S.R. Stock, Elements of X-ray Diffraction, Third Ed., (Prentice Hall, Upper Saddle River, NJ, 2001).

13. R. A. Varin, J. Bystrzycki, and A. Calka, Intermetallics, 7, 785 (1999).

14. U. Demircan, B. Derin and O. Yucel, Mater. Res. Bull. 42, 312 (2007).

15. J. Y. Lok, MSc Thesis, Virginia Polytechnic Institute and State University, Virginia, 2006. 